\title{
The Institution Of Purdah: A Feminist Perspective
}

\author{
Riffat Haque \\ Department of Women's Studies \\ Allama Iqbal Open University, Islamabad
}

\begin{abstract}
Though purdah is associated with Islam and Muslim traditions, its origins can actually be traced to pre-Islamic times and other religions such as the Jewish, Christian, and also to non-religious sources of influence, such as to the Hellenic, and the Bedouin cultures. Most religious and cultural systems in the world endeavor to control men's and women's lives and activities in order to ensure the continuity of society, although the extent of control exercised over women varies from one culture or religion to another. The institution of purdah has religious and cultural origins and has implications for every aspect of women's lives. The practice of purdah manifests in various forms: seclusion, forms of dress, and segregation of women in the society. Indeed purdah has had multiple and changing meanings throughout history, although gender issues have always been a part of its practice. The widespread research on Muslim women's practice of purdah, confirms that there are multiple meanings of purdah which are influenced by internal and external factors in each country. Subsequent investigation is an attempt to trace the origins of purdah/veiling and its manifestation and intertwining impact on women's lives.
\end{abstract}

$$
\begin{aligned}
& \text { تلفيص المقاله }
\end{aligned}
$$

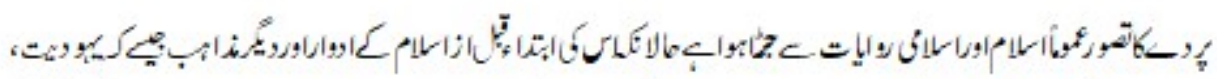

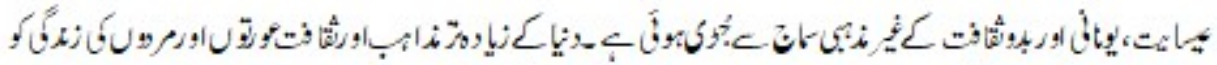

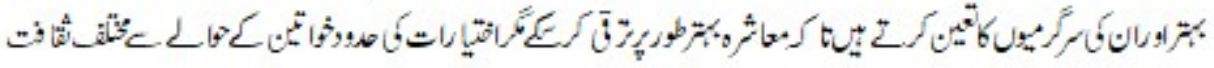

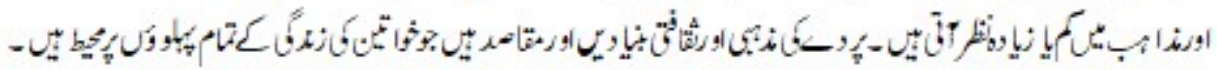

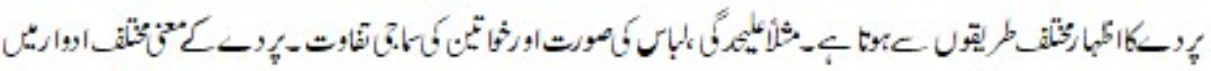

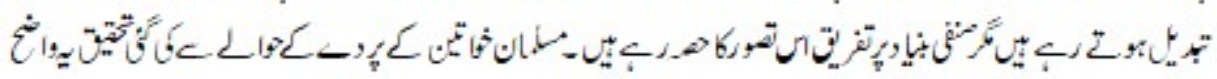

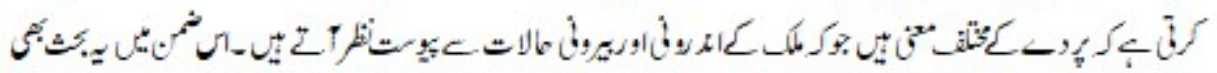

$$
\begin{aligned}
& \text { 若 }
\end{aligned}
$$

\section{Purdah and Related Terms}

The word 'purdah' has different spellings: purdah in Urdu language, pardah in the Persian (Farsi) language, and pardah in the Hindi language (Britannica.com, 2000). ${ }^{1}$ It literally means curtain, cover, veil, privacy, modesty and secrecy (Donzel 1978). Though 
there has been no semantic study of this term, it is widely used throughout South Asia (namely Afghanistan, Pakistan, India and Bangladesh) referring to the seclusion of women from the public gaze by means of screens, curtains, high walls, concealing clothing and by segregating women from men in the society. The local vocabularies typically have a variety of words to refer to different aspects of these complex behaviors, which can be lumped together under the term purdah (Papanek 1982: 57- 58).

In other Islamic countries various additional words with similar meanings are also used to refer to the seclusion of the sexes and covering of face and body (Donzel 1978: 359). Widely used synonyms are 'Hidjab'2 'Purdah', 'Jilbab', 'Chador', 'Veil', 'Burku', 'Mantle', 'Khumur', and 'Harem'.

Hijab is basically derived from Arabic word Hidjab meaning to hide from view and conceal. It implies wearing clothing to physically hide or conceal. Veiling on the other hand is an English word meaning the wearing of a head- gear that covers the hair and lower part of face (Kader 1984: 146). The larger impact of these practices is the same whether it is referred to as purdah in Pakistan, Afghanistan, Bangladesh and India; or the turban in Turkey, chador in Iran and Afghanistan, or hijab in Egypt, and other Middle Eastern countries and North Africa (El Guindi 1999; Ahmed 1992; Mernissi 1987\&1991; Shaheed 1987; Papanek 1982 and Saadawi 1980).

\section{Historical Perspective of Purdah Tradition}

Most religious and cultural systems in the world endeavor to control men's and women's lives and activities in order to ensure the continuity of society, although the extent of control exercised over women varies from one culture or religion to another. Although purdah is nowadays always associated with Islam and Muslim culture, its origins can actually be traced to pre-Islamic times and other religions as well and non-religious sources (Jewish, Christian, Hellenic, Bedouin for example) (Hassan 2001: 60). The status of women in pre-Islamic cultures from Mesopotamia until the seventh century A.D. demonstrates a cultural legacy ${ }^{3}$ inherited by Islamic societies, when the women of wealthy and powerful tribes were veiled and secluded as an indication of protection and status (Wadud-Muhsin 1992: 10; Keddie 1996: 2; Bodman \& Tohidi 1998: 3). Ahmed's (1992a) extended survey revealed that the wide and continued use of purdah (veiling and seclusion) for millennia prior to Islam were part of an institutional structure and ethos in Greek and Byzantine societies. In Mesopotamia, rules of purdah veiling were detailed in an Assyrian legal text of the thirteenth century B.C., the practice being linked to respectable women and prohibited for prostitutes (Ahmed 1992a: 11- 30: Keddie 1996: 3 ). Athenian women of status were secluded and veiling existed in the Greco-Roman world. Seclusion existed in pre-Islamic Iran and the Byzantine Empires. Before the emergence of Islam, covering of the head was prevalent in early Judaeo-Christian tradition by the women of the upper elite class (Mohammad 1995; 21- 22). El-Guindi's 
(1999: 12) historical analysis of the records reveals that seclusion and veiling correspond more with Christian (Mediterranean/Balkan) culture than with Muslim society. Muslim conquests and contact with Greeks, Romans and Assyrians, where the veil ${ }^{4}$ was prevalent and considered a status symbol among the upper class, influenced the Islamic culture (Engineer 1999: 8; Ruthuen 1984: 72; Mohammad 1995: 25).

During Prophet Mohammad's (PBUH) time women participated publicly in the social, political, economic and religious life. For example, his wife Hazrat Khadijah, was a successful trader, another wife Hazrat A'isha, took part in wars and was the transmitter of the majority of ahadith. Women participated in religious congregations, and large numbers of women participated in the oath of allegiance to the Prophet (Stowasser 1996: 27- 28; Korvin 2000: 35). The Quranic revelations regarding purdah each occurred in a certain context and in particular circumstances. The language and cultural context in which the text was subsequently read, and the intent of the interpreters, influenced the later manifestations of purdah. The veiling of the Prophet's wives probably encouraged the more general adoption of veil (Ahmed 1992a: 56). Hazrat Umar (the second Caliph ${ }^{5}$ ) was convinced that women should be segregated, and on various occasions he suggested to the Prophet that he ask his wives to be veiled. But while there are ample examples of women's active participation in the society (Engineer 1999), after the death of the Prophet, Hazrat Umar barred women from worshipping in the mosque or going by themselves to pilgrimage (Korvin 2000: 36).

Gradually, by the tenth century A.D. the women's status took a downward slide in Persia under the Abbasids, when the custom of seclusion in harem and segregation of sexes was enforced (Mernissi 1991: 194-195), but the common women and slave girls went about unveiled (Korvin 2000: 32). When the Turks captured Constantinople (1453) and within a century conquered most of the formerly Arab territories, they also adopted customs of the conquered, including the veil and harem. However, the practice of purdah has never been a universal custom for Muslim women, as a great majority of peasants worked in the fields and for them the face veil was an absurd encumbrance (Hofmann 1999: 80). According to Roded (2001) during the last two decades new research on the roles Muslim women have played in the social, economic, warfare history and cultural life raises the question of how seclusion of Middle Eastern women was maintained, until now seclusion has been a defining factor of the status of women in these societies.

In the context of the Indian subcontinent, for women of the pre-Turkish period 'the existence of pardah though not very common, cannot be completely denied' (Misra 1967: 2 ) and 'as a rule was confined to kings, nobles and merchant- princes in pre-Muslim India' (Thomas 1964: 247, 350). Although some form of seclusion existed before Muslim rule (Brijbhushan 1980: 19; Altekar 1956: 169-175), after the invasion of Muslims (eleventh century onwards) the practice of purdah became more common in the local society. The local adoption of purdah was not only an imitation of the invaders' practice, 
but was also useful as a protective measure to save their honour from the Turkish invaders (Misra 1965: 134; Kaur 1968: 24). The upper class Muslim and Hindu women thus adopted purdah, and while going out used covered palanquins. ${ }^{6}$ The women of middle and lower class did not follow this practice while going out (Thomas 1964: 250; Kaur 1968: 25). The purdah practice of Hindus and Muslims had basic difference: Hindu women's purdah was much more rigid within the family (Minturn 1993), whereas Muslims' practice was vis-à-vis outsiders (Jacobson and Wadley 1977). But the main purpose for both Hindus and Muslims was (and still is) exercising control over women (Lateef 1990). By coming in contact with Hindu culture, Muslims also adopted aspects of the customs, manners and social life of the Hindus (Thomas 1964; Ali \& Mills: 2001: Jeffery: 1979/2000). Zarina Bhatty (1976: 99) argues that the Muslim women in India inherited the restrictive components of both the cultures, in the form of Islamic injunctions and as well as the complex customs and caste rules of Hinduism.

In a lecture at Madras in 1927, Pickthall ${ }^{7}$ strongly criticized the Indian subcontinent's style of purdah, which involved covering of the women's face, segregation by impounding women and consequently condemning them to a life entirely within four walls of the house (Ali \& Mills 2001: 3). While analyzing the Indian purdah system adopted by Muslims Pickthall calls it cruel because,

'they (Muslims) came into this land as conquerors, with ambitions and ideas befitting noblemen and rulers in Afghanistan and Turkistan and Persia...so that now every Indian Muslim thinks it is necessary for their Izzat [honor/status] to treat his women in, perhaps, a wretched hut as the original Beg or Khan Sahib [people of higher and noble social status] treated the women of his household, or as Mughal Emperor treated the women of his palace. It is the lack of peasantry, which had made them confuse the Purdah system of the wealthy town folk in the past with the Sacred Law of Islam. If there had been a Muslim peasantry in India, ... [they] could never have fallen into the error of supposing that the Purdah system should be practiced by the poor who dwell in hovels, and the rich would never have applied both to town and country life' (Ali \& Mills 2001: 10).

Due to the multiplicity of expressions of Islam in different historical and cultural contexts (Hussain 1984: 3), one finds diversity in purdah. Traditionally the most veiled and secluded women are from the urban upper class. In Muslim countries the position of women fluctuates between the Quranic words and local customs and traditions based on extra-Islamic conditions, which are often justified to the people by twisted meanings and misinterpretations of Quranic injunctions that are an abuse to the Islamic Law (Engineer 1992: 4; Kader 1984: 142). The role norms for women vary from one Muslim society to 
another, yet in-spite of disagreements over interpretations of religious functionaries or patriarchs; all shares the view that women should occupy a subordinate role.

\section{Islamic Interpretation}

As briefly described in the preceding section, veiling was a practice among most of the nations of antiquity. However, it is necessary to examine specific links between purdah and Islam.

The Islamic injunction regarding purdah can be traced from the fifth hijra[8] (AD 627) before the Prophet Muhammad's death. Muslim jurisprudence (Hofmann 1999: 74) in Islam is derived from:

The Quranic': $\quad$ concept: written words from the holy book of Muslims.

The Sunnah ${ }^{10}$ : the model behavior of the Prophet Mohammad.

The Hadith ${ }^{11}$ : $\quad$ heritage carried from the Prophet's times.

The Shariah: the Islamic Law and Ethics.

The Fatawa: the Legal decisions by a religious authority.

The Maslaha: $\quad$ Legislation derived from Islamic principles based on public interest.

The Quranic exegesis and the collections of Hadith are classical compendia for the followers of Islam. The development of Islamic Law and jurisprudence was influenced by multiethnic and multicultural contexts, all of which were patriarchal. Islamic intellectuals, ulema, jurists, and scholars of various ideologies (conservatives, traditionalists, modernists and fundamentalists) have specific interpretations. Hofmann (1999: 75) categorizes these scholars as follows:

Those who maintain that the Quranic norms were only meant to regulate the earliest Islamic community ... and are no longer relevant and binding.

Those who flatly deny that the Quran contains only broad guiding principles.

Others who try to reduce to a minimum the legal content of Shariah by emphasizing the normative quality of the Sunnah or by rejecting many a relevant Hadith as spurious.

Those who believe in the static interpretation of Quran and Hadith, and want it to be strictly implemented. Those who believe that human reason are not a means to an end, but a key to open secrets and to re-adapt the religious beliefs to new possibilities.

After the expansion of Muslim territories, the evolution of Islamic Law was influenced by the traditions of the new regions. Islamic jurists merged Quranic precepts with local practices. Hence, Sharia differs from one region to the other. Ultimately in the mainstream $^{12}$ of Islam, there are four schools of law, which are Shafiites, Hanbalites, Malikites and Hanafites (Bodman 1998: 10). Over the course of time, differences of opinion developed between these four schools with regards to the limits of hijab. The first two schools were more conservative and believed that the entire body of the female 
should be concealed. The interpretations of the latter two schools were more relaxed about the covering of face and hands (Stowasser 1994: 131).

\section{The Quran}

In the Quran the word Hijab has been used seven times both in concrete and metaphorical terms (Donzel:1978): concrete in regard to women's hijab, and metaphorical in reference to other situations when an intellectual meaning of concealment or hiding was suggested. The verses of the Quran and the sayings of the Prophet of Islam are not related to a single period of time, but span many years. Each verse is linked to a particular circumstance and incident in respect of place and time. There are two chapters (Surrah) of the Quran in which there is a specific narration ${ }^{13}$ about clothing and public behavior; segregation and staying in the house. These are:

1. Surrah Al-Nur (Light, 24)

2. Surrah Al-Ahzab (Confederates or The Clans, 33)

In Surrah Al-Nur reference is made to:

- Restraining of eyes, and

- Prohibition of display of fineries.

Verse 24: 31 says,

'Tell the male believers among you that they are to lower their gaze when in the company of others and preserve their own modesty. Sexual modesty is better for those who believe, and more conducive to purity. And God is perfectly well aware of all that you do' Turner (1997: 211).

In the next verse (24:32) again the Prophet is guided to,

'Tell the female believers among you that they too are to lower their gaze when in the company of others and preserve their own modesty. They are not to make a display of either their natural beauty or their artificial ornaments: their legs are to remain covered, except for those parts exposed naturally when walking and they are to keep their hair covered with a scarf or shawl (writer's emphasis) which should be tied or pinned under the chin. They may display their beauty to no one except their husbands, their fathers, their husband's father, their sons, their husband's sons, their brothers, their brother's sons, their sister's sons, their maids, their slaves, male servants in their household who are free of all carnal desire, and children who have no sexual knowledge. Women believers must take care not to draw attention to themselves by walking in such a way that whatever lies beneath their outer garments becomes 
exposed. And $\mathrm{O}$ you who believe! Turn towards God in a spirit of reconciliation and dress yourselves in modest attire so that you may escape the punishments of the Hereafter and attain eternal felicity in the Garden of Paradise.'

It is noteworthy that, while both male and females are being directed to lower their gaze and preserve their modesty, the females are being guided in much more detail with mention of specific relatives in front of whom they can be casual. The scarf as a head covering is not mentioned in the original Arabic writing of the Quran, where only the cover of the breasts is mentioned.

Abul Ala Maududi explains that the commandment does not mean that people should always cast their eyes down and never look up, but that it cautions against 'adultery of the eyes'. Enjoying the beauty and decoration of other women by men, and making other men their object of the eyes by women, is liable to lead to sexual tension and possibly adultery (Maududi 1934: 180).

In the verses of the Quran (24: 32) quoted above there are some specific instructions stating that women are required not to display their decorations. Maududi (1934: 187) explains that because women by nature are fond of decorating themselves, they may do so, but only in a limited circle as guided by God. The purpose is to reduce the chances of emotional excitement or sexual anarchy that can result from female charms and decorations. However, (Engineer, 1999: 72) suggests that the Quran deliberately used vagueness regarding the covering of the body by using the phrase 'except what may decently be kept open'. One can not be sure of the intent but he is right in suggesting that the understanding of the phrase will always be culture-specific, as is evident in the Muslim societies across the world.

In Surrah Al-Ahzab, God is addressing the Prophet's wives. The translations of selected verses, are related to:

- Speaking quietly and modestly.

- Modesty in dress.

- Remaining within the house.

In verses 33: 33, 34 and 60 God addresses the wives of the Prophet,

'... [If] you continue to fear God and do good works, you will remain on a different plane to that of other women. Thus speak quietly and modestly when conversing with strangers; do not make a show of your voice lest one of the muhajirs (refugees) in whose heart there is a disease be smitten with desire. In order to preserve your God fearing character, speak only of serious matters when conversing with strangers; do not broach topics of 
a sexual nature lest their passions become inflamed. While you may possess the maturity for such discussions, they may not' (33: 33).

'Remain calmly and quietly in your houses and do not display yourself from the windows, doorways and roofs, as was the custom of women in the Age of ignorance' (33: 34).

'O Prophet! Tell your wives and daughters, and all believing women, to dress modestly when leaving the house: they should wear a cloak-like outer garment or a veil, which they are to wrap around themselves in order to conceal their figures. Their dress serves to identify them as women of modest mien for whom intimate contact with is strictly forbidden, thus helping to prevent harassment and intimidation. In blocking the path to errors and misdeeds God demonstrates His forgiveness and His Mercy' (33: 60) (Turner 1997: 252- 254).

In the first two verses the reference to purdah is in the context of life in pre-Islamic Arabia, when women, despite social and legal restrictions, freely moved and indulged in amorous talk with strangers and acquaintances, or mixed with them (Siddiqi 1979: 153). Islam directed women to live a decent life, prohibiting them from displaying their charms and developing interests outside of the house and family. And in the next verse emphasis is laid on precautions for women when they go out. If the intention was to prohibit women's movement out of their homes then reference to covering would have been meaningless. Therefore according to Ibn Abbas (quoted in Siddiqi 1979: 155), to prevent the observance of bodily features and charms, an over-garment (jilbab) was required for women when they went out.

According to Mernissi (1991: 85-101) the origin of the hijab apparently is related to the cloth hijab, which was a material object, a curtain (which is revealed in Surrah 33) that the Prophet drew between himself and Anas-Ibn-Malik (a third male person) who was at the entrance of his nuptial chamber. Thus these verses may be interpreted as protecting the intimacy of Prophet and his newly wedded wife, Zaynab-Bint-Jahsh. It is told that on the wedding night some guests stayed overnight at the Prophet's house and then in the morning the Prophet saw some people loitering in the vicinity. Tradition also relates the insistence of Umar-ibn-al-Khattab (the second caliph of Muslims) on the segregation and concealment of the Prophet's wives because all types of people came to the Prophet for guidance. Muslim interpreters mention that the Prophet's wives did participate in the communal life of Medina before this revelation. The dwellings of the Prophet's family were adjacent to the mosque where throngs of people came to seek advice and have an audience with the Prophet. As the living quarters were so close, privacy was not possible. 
It is believed that in order to provide privacy and comfort for the women, the revelation of hijab was imposed (Stowasser 1994: 90- $91 \& 116$ ).

The political and social conditions giving rise to these revelations (Mernissi 1991) during that period allowed 'hypocrites' (non-believers who sometimes pretended to be Muslims and were involved in subverting Islam) to create communal tension in Medina. Therefore the wives of the Prophet and other believing women were required to distinguish themselves from slaves by wearing an outer garment as a mark of identification from others, so that they would not be mistreated by the hypocrites. It has been argued that in the present times, in Muslim societies where such an outer garment is unnecessary as a signifier of being Muslim, and then subjecting women to such a practice would not fulfill the true objective of the Quranic decree (Hassan 2002).

Fazlur Rehman writes that, '... the Quran does not give any general rule, but it gives solutions and rulings on specific issues and ... rationale behind those solutions from which one can draw general principles. Building an authentic set of Islamic Laws... involves a three-part process, which requires a radical departure from past and present practices. First, in arriving at general principles or statements from the Quran, one must first give due consideration to the socio-economic conditions then existing, for the general principles are embedded in actual cases ... which the Quran discusses, from which they must be disengaged. Second, these general principles or statements must be placed in the context of the general principles on which the entire teaching of the Quran coverage. Third, step is to move the general level to the specific legislation now sought (after), keeping in view the present societal conditions and developments in the world' (Rehman 1978: 136- 137).

\section{Hadith}

There are many Hadith ${ }^{14}$ which refer to specific instances in which the Prophet had guided people. The emphasis on purdah in Islam emerges more from Hadith than from the Quran. Although there are many Hadith, a few examples of those that deal with the behavior expected of women and men in relation to each other are mentioned below:

1. Hazrat Jarar says, "I asked the Prophet what I should do if I happen to cast a look by chance". The Prophet replied, "turn your eyes away" (Siddiqi 1979).

2. According to Hazrat Buraida, the Prophet told Hazrat Ali not to cast a second look, for the first look was pardonable but the second was prohibited (Siddiqi 1979). 
3. Mughirah bin Shabah says, 'I sent a message to a woman for her hand. The Prophet said to me, I have a look at her, for that will enhance love and mutual regard between you' (Khan 2004).

4. According to Sahl bin Sad, a woman came to the Prophet and said that she intended to offer herself in marriage to him. Hearing this, the Prophet raised his eyes and looked at her (Khan 2004).

5. Hazrat Umm Salmah relates, one day she was sitting with the Prophet along with Hazrat Maimunah (Hazrat Aishah according to another report) when Hazrat Ibn Umm Maktum, who was a blind man, called on the Prophet. The Prophet told them to observe purdah in his presence. Hazrat Umm Salmah said, 'Is he not a blind man? Neither will he see us, nor recognize us'. The Prophet said, 'Are you also blind?' (Ali 2004).

6. The Prophet told Fatima, daughter of Qais, to pass her waiting term (during which a widow or a divorced woman is not allowed to marry) in the house of Ibn Umm Maktum, the same blind man from whom Hazrat Umm Salmah had been instructed to observe purdah. Abu Bakr Ibn Arabi relates that Fatima wanted to pass her waiting time in the house of Umm Sharik, but the Prophet did not approve of this for the reason that many people visited the house. Therefore she should stay in the house of Umm Maktum who was a blind man (Mernissi 1993).

A reasonable conclusion from the above a Hadith is that it may be wise to avoid unnecessary intermingling of men and women in the society. However, socially constructive interactions between men and women do not appear to be precluded.

The concept of covering emerges in the context of maintaining the moral character of women in mixed gatherings by requiring them to follow an overall code of conduct, which includes manners, speech and appearance. It appears that women's seclusion per se is not the purpose, because during the time of Prophet and in later Muslim history, women were involved in a wide range of activities. In the Hajj (Muslim pilgrimage to Mecca) there is no segregation of males and females, and no covering of women's faces. The covering of Muslim women (and the Prophets' wives in particular) was to protect them in a particular set of circumstances.

\section{Practices / Manifestations of Purdah}

Having traced historical and religious influences on the emergence of purdah, it is now appropriate to describe in detail the various ways in which purdah is currently practiced. The practice of purdah incorporates three main concepts: firstly, the seclusion of women in the private space of their living quarters, thus avoiding public exposure. Secondly, the garments use to hide themselves from men if women do have occasion to go out into public space. And finally, to keep women segregated from men both in public and private space. These three concepts overlap in shaping women's lives. 


\section{Seclusion - Restriction to Family Living Quarters}

A woman's seclusion is linked to her chastity, which in turn is actually linked to the honor of the men in her family. To uphold the honor of their men, secluded women do not leave the chaddar and chardivari (four walls of the house, idiomatically used for the institution of purdah). In cases where seclusion within four walls is not possible for women, then an external symbol of respectability is adopted in the form of dress. Seclusion is a status symbol that is adopted by wealthy women to indicate their affluence (Hafeez: 1991; Zafer: 1991; Klein and Nestvogel: 1992). Poorer women may also remain secluded at home, but the economic pressures of life necessitate that these women do home based, low paid work. Rigid purdah is not possible in rural areas where the majority of women fully participate in agricultural production. For rural and urban lower middle-class women purdah dress and seclusion are considered to be luxuries, which would enhance their status and allow freedom from physically tedious work (Mumtaz and Shaheed: 1987; Klein and Nestvogel: 1992). The practice of purdah is also influenced by family norms, and may vary according to both the woman's and the family's economic status and ethnic identity as well.

\section{Range of Purdah Outfits Prevalent in Pakistani Culture}

In Pakistan, the degree of purdah covering used by women who enter public spheres varies, and is reflected by the adoption of different purdah dresses in different socioeconomic situations. The type, color and quality of material used of purdah outfits are associated with the wearer's status, also signaling the wearer's class, wealth, sophistication and region of origin. Hanna Papanek refers to the physical aspect of purdah (i.e., the forms of attire) as instruments. The women use these instruments as a logical supplement to seclusion, and as a kind of portable seclusion for coming out of their enclosed living spaces (Papanek 1982: 10).

There are great ranges of purdah outfits, which are prevalent in the Pakistani society. Variations of purdah out fits can be described as follows:

$\underline{\text { Burqa }^{15}}$ : Two types of burqa are:

1. A tent like garment that covers whole body and head, including the face, commonly referred to as 'shuttlecock burqa'.

2. A two piece out-fit with a loose cape that covers from shoulders to feet, plus a loose head covering (some cover the face, others do not) that falls to the waist.

Nikab: Cloth that covers face from below eyes, or with slit for eyes. Worn separately but mostly in conjunction with two piece burqa, chaddar or scarf as well.

Chaddar: Large length of cloth that is loosely wrapped around body, and draped over the head. Shorter versions of chaddar that are simply draped around shoulders are also in trend.

Scarf: Covering for head (not face) and shoulder's tied under chin. Young girls prefer to wear it alone though it is also worn in conjunction with chaddar and coat. 
Coat: Full-length garment with sleeves that covers the body also supplemented by scarf. Duppata: Duppata is a two and a half to three-meter cloth, which is used to cover the head and body at least to the hips. It is part of the women's national dress of Pakistan, which is practiced at all times and everywhere worn in conjunction with the shalwar (slack pants) and kamiz (knee length shirt). Mumtaz and Shaheed (1987: 75) consider it as national dress of Pakistan but not a Muslim dress.

The above description is not complete, as there can be many variations associated with the fashion, aesthetic sense of the wearer, age, social and economic status, class and region. The main purpose in describing these is to give the reader a perception of the extent of body covering with each type of garment. As these terms were used extensively by the participants interviewed in the research, it is important that their meaning is clear.

\section{Segregation in Public Places}

Segregation refers to the separation of men and women in public places. It is used in conjunction with dress codes, when it is deemed necessary or acceptable for women to leave the seclusion of their homes. A purdah society depends on an underlying value system related to segregation of the sexes, which is reflected in various degrees of observance. Different types of segregation provide different degrees of opportunity for conformity (Papanek 1982: 10). For example, segregation by space may provide a wider range of behavioral opportunities than are possible for women in a mixed gathering. The segregation of the sexes divides the society in work places, in educational institutions, in private and official functions, in local transport, in sports ${ }^{16}$ etc. The Government has recently opened a separate women's university, which was a long-standing demand from different sections of the society. In many coeducational institutions a minimum requirement is for the women to wear a scarf, and to observe other measures of segregation between males and females. Many families do not allow women to undertake jobs in offices where they have to interact with non-kin men. Some organizations also avoid employing women applicants, as then extra facilities such as transport, toilets, daycare, and security, need to be provided. Women's participation in spectator sports is also considered un-Islamic and therefore segregated sports with female-only audiences are encouraged. Segregated fairs, parties and educational events also take place. Thus women are conditioned to live in a segregated society that they not only accept, but in which they rather feel more comfortable (Mumtaz and Shaheed 1987).

\section{Implications of Purdah}

Gender is one of the organizing principles of Pakistani society, and patriarchal values predetermine the social value of gender. The sexual division of labor places women in reproductive roles in the private sphere and men in a productive role as breadwinners in the public sphere. The level of resource investment in women, by both the family and the 
State, is low. The complex set of rules which governs all gender interactions, is based on the institution of purdah, which, as just described, is not merely the physical adoption of a veil or segregation in the homestead. In fact it is argued in this thesis that the institution of purdah is a tool for controlling women and buttressing the patriarchal structures of the society. The research data presented in later chapters shows that the overarching implications of the practice of purdah have two forms: the visible that is manifest in seclusion, particular dress and the segregation of the sexes, and the invisible, which is prevalent in the underlying attitudes of society, and in the control of women's lives by those who use religion and tradition as their means to do so. Generally the overt forms of purdah are apparent, but it is the covert government policies, legislative/judicial regulations which ratify the institution (enforcing discriminatory policies) that actually affect women's status (Haque 2002).

The complex inter-linkages between the visible and invisible forms of purdah interact to determine the oppressed status of Pakistani women and their lesser opportunities to participate in society. As a result, women are discriminated against and deprived of many basic facilities by decision-makers who consider that, due to purdah, women probably do not need or cannot access health facilities, education, and employment opportunities. Female chastity and honor are bought into play, and restrictions are imposed on the whole field of interaction between the sexes (Ismail 1998: 214). Such socio-cultural disparities are further compounded by an absence of legal and political recognition of women. Thus, the combination of the visible and invisible forms of purdah creates an interconnected web of deprivation, marginalization and denial, not only of women's rights for self-improvement, but also of their roles as agents of change.

Over the last sixty years the dynamics shaping the relationship between women and the State have revolved around the 'imperfect nature' of women's citizenship under Pakistan's secular regimes. This has represented a violation of successive constitutions, which in theory award equal rights to men and women, as does Islamic Law as well. The State does not recognize women's autonomy and separate status and has actively made laws that negate women's identity. It fails to perceive peculiarities of the women's situation. Women's rights are restricted and limited in the name of protection for them, which is at best a circular argument. The legal system creates contradictions and duality in both public and private spheres, which is compounded when the courts reflect public opinion to a great extent, for example, in family case laws (Gilani 1990; Pearl 1990, Lawerence 1998). According to a Pakistani legal academic, biased legislation and orders serve to reinforce society's discriminatory attitudes towards women (Ali 2000). A tendency to view women in a fragmented manner by the planners and policy-makers is evident in the discrimination of the legal and institutional scaffolding, bolstered by the societal attitudes. The response of societal institutions renders even progressive laws ineffective (Jilani 1994: 103). Thus women continue to suffer from an ad hoc judicial review system, subject to manipulation rather than consultation (Lawerence 1998). 
The Constitution of the country places no restriction on women's participation in politics; nevertheless, their presence in political structures remains insignificant as a result of cultural and structural barriers.

Compounding their ineffective voice in political areas, women are also disempowered in legal arenas and recent amendment in Hadood Ordinance has not served the purpose. Generally, due to women's lack of awareness in relation to their rights, their suffering in matters of litigation is compounded by a biased judiciary, law enforcing agencies, a lack of female lawyers and judges, the costs of litigation and delays in the justice system (Ali 2000).

\section{Feminism and Purdah}

This overview of the literature on purdah requires the reader to take note not only of its multiple meanings, but also the diverse interpretations, its cultural and political conditioning and its sensitive function as a metaphorical marker of collective and personal identity.

The history of Muslim societies reveals that the segregation of the sexes has been determining factor in defining gender roles. In the last two centuries, the use of purdah has contributed to positioning women in the modern world, functioning as a lever in the search for identity. The reality behind purdah-clad women is complex and varies from place to place. On the one hand it signifies identity with religion and ethnicity and on the other hand it is used in negotiating women's personal identities, thus challenging the existing relations between women and men.

It is important, however, to acknowledge that there are multiple contexts and rich spectrum of motivations and meanings (Bullock 2000; Haddad 1982; MacEOIN \& ALShahi: 1983; Wassef 2001; Ahmed 1992b; Tohidi 1991; Jeffery 1979; Saadawi 1980; Mernissi 1987; Papanek 1982) to consider in understanding why women observe purdah in Muslim societies. The reasons are very complex and vary according to their class, region, nationality and culture. Broadly, these appear under twelve categories: religious, related with faith; psychological, choice of authentic dress; political, a challenge to political norms such as revolutions against colonizers, bourgeois nationalists and secular rulers; revolutionary, Islamization of the society; economic, status symbol denouncing leisure. To continue with the categories there is cultural adherence to norms and values of chastity and protection from public gaze; demographic, it identifies with urbanization and social status; domestic, symbolic act of detachment from public sphere to derive respect for themselves and gain respect for men with whom they are identified, especially for working women, 'escape' from strict attitudes within the family. In the personal context women who choose to wear purdah for reasons other than that of religious significance, may do so to be 'modern' to keep up with latest fashions or refusal to fashion. Purdah is 
status symbol, it is related with honor and shame and lastly also as source of power. From a feminist perspective the motivation for the revival of purdah is that it acts as an empowering tool (Hosseini 1996: 156) for women, linked with their identity, and access to public space. While it restricts some women, it emancipates others by legitimating their presence in public domains. Although all these themes converge and overlap with one another, when purdah is a willing choice of women for education and economic independence, then it has gained a different meaning in modern desegregated societies that is of both protection and increased freedom of action (Afary 1998).

In contrast to such 'modern' contexts, in 'traditional' societies it is widely assumed by the feminists that the protection and logic of modesty embodied by purdah in Islamic life has taken on the shape of oppression, effectively alienating women from public life and ensuring the segregation of the sexes.

It is interesting to note that any debate, past or present, about women's rights in Islamic countries revolves around purdah. Moreover, in Muslim society feminists are judged by their support or otherwise for the practice of purdah. It is evident in the literature that since the 1970's purdah has been used as a political strategy and symbol, which highlights the ambiguities of modernization in Muslim countries. The revivalism of Islam on the one hand is a reaction to the political, cultural and social pressures from the modern West (MecEION and Shahi 1983: 36) but on the other hand this revivalism also results in the rediscovery and reassertion of a Muslim political, social and cultural identity.

In the Muslim world the present state of purdah (veil and hijab) has undergone an obvious shift from the initial goal of creating women's general societal segregation and invisibility, to a garment which symbolizes various challenges. Consequently the present situation of purdah is not only a matter of the simple submission of women to male dominance. Rather, purdah practices can negotiate a more positive position and role for women within Islamic countries, thus positioning its practice as a strategy of resistance and liberation, rather than only an emblem of submission. This could mean that women who choose to observe purdah are carving out their private space within outer public space and ensuring greater mobility in a society that does not welcome women's participation outside of delineated boundaries (Wassef 2001; El-Guindi 1999). It is also argued that purdah-clad bodies have given a powerful visual symbol to Islamization and carved out a new profile for Muslim women, accentuating their difference from Western cultural models. In effect this use of purdah has led to the recognition of Muslim women worldwide (Maumoon 1999: 267) which advances a new semantic language against Western civilization (Afary 1998; Gole 1996).

Since the latter half of the twentieth century the Muslim world has been providing two mixed messages. On one hand there are Islamist movements, which call for the return of 
women to their traditional roles in the home. On the other, there are active, militant and assertive women who seek the opportunities provided by modernism by adopting purdah so that they are no longer confined to the home. This public and political manifestation of the female body gives a new meaning to Islamic civilizational shift (Gole 1996: 84- 86). By adopting purdah (veil, scarf, hijab, chaddor, turban) these women exercise control over their behavior and limit their appeal to men, and in so doing defend their own honor. The nineteenth and early twentieth century use of purdah was linked to the rich and elite classes as a status symbol, but it has now shifted to be identified also with the educated middle classes.

The plethora of research on Muslim women's practice of purdah, confirms that there are multiple meanings of purdah which are influenced by internal and external factors in each country. Indeed purdah has had multiple and changing meanings throughout history, although gender issues have always been a part of its practice (Badran 1995: Mojab 1998). In the early $20^{\text {th }}$ century anti-colonial nationalist movements for example, in Algeria, Egypt (Boutta 1994; Cherifati-Merabtine 1994), the Indian subcontinent (Minault 1982; Saiyid 1998) and Tunisia (Charrad 1998), and the veil was used as an icon of nationalism and Islamic culture. In Iran (Nashat 1983; Hosseini 1996)) and Turkey (Gole 1996), where the state was involved in imposing the 'unveiling' of women in the late 20th century till recently, re-adoption of the veil is being used to symbolically challenge the secular governments that once were sponsors of unveiling. Now once again in Iran a movement exists campaigning against compulsory veiling while in Turkey the university students have adopted veiling as a sign of identity and protest. In countries like China, where Muslims are in minority, it fosters separate identity and ethnic consciousness (Jaschok and Jingjun 2000). These are clear examples of how the resurgence of Islam has made an impact on Muslim women who are adopting purdah dress in different forms as an outward sign of cultural and ethnic identity.

Thus purdah has gained considerable popularity due to its political use, both by the state and women themselves (Stowasser 1994; Hijab 1988). This is particularly apparent when examining the purdah practices of the educated and working middle class, where it is worn as a badge of both morality and cultural authenticity while in the public sphere (Stowasser 1994: 131; Hijab 1988: 51). Keddie and Beck (1978: 9) argue that 'the growing forces of education and employment opportunities, plus the increase in women's activity on their own behalf is eventually causing the elimination of the forced use of the veil, thus leaving it as at the most, a variable item of women's choice'. While there is a strong trend for re-veiling by women themselves, supported by religious leaders, there are also secular and left minded people in Muslim societies who denounce compulsory veiling and seclusion and consider its enforcement as oppressive to women. However their voices are very often silenced (Tohidi 1998) and so the element of 'choice' in taking the veil really remains a displeased question. 


\section{End Notes:}

${ }^{1}$ These three languages, Farsi, Hindi and Urdu are languages of the Indian Subcontinent. Farsi disappeared from the subcontinent after the Mughals but is spoken in Iran and parts of Afghanistan. The Hindus of India speak Hindi and Urdu is the National language in Pakistan.

${ }^{2}$ Hidjab is commonly spelled as hijab and higab as well.

${ }^{3}$ The need to control women originates from the issue of inheritance through the male line. Thus female virginity and fidelity became of central concern, and women's contacts with males were restricted to determine the fatherhood of children (Keddie 1996: 3).

${ }^{4}$ As reported by El-Gundi's the ethnographic analysis of veil and seclusion (both can occur separately). In the social space it is linked with themes such as power, privacy, authority, rank, resistance and liberation (1999: 126-127).

${ }^{5}$ A leader of an Islamic polity, regarded as a successor of Muhammad.

${ }^{6}$ A fully covered small bed or chair on which rich women used to go out.

${ }^{7}$ Marmaduke Pickthall was a British Muslim convert who is known for his highly regarded English translation of the Quran.

${ }^{8}$ Hijra is migration of the Prophet Mohammad from Mecca to Madina.

${ }^{9}$ The Quran is the book revealed to the Prophet Mohammad, the Messenger of God. It is composed of 114 Surrahs (chapters) each divided into verses. There are 6,219 verses).

10 The Sunnah is the way of acting, the behavior of the Messenger of God, by word, action and silence. The believers need to follow Him. The Sunnah is a source of laws similar to the Quran (Sabbah 1984: 7).

${ }^{11}$ Hadith are statements of the Prophet's contemporaries. An account relating to a deed or decision attributed to Mohammad. An authentic documentation of some practices, whose composition has two parties to it: a chain of authorized persons certify that the transmission of the account was made from one person to another from the last narrator to the first transmitter...'so-and-so told us, according to so-and-so, who heard it from so-and so who got it from so-and-so... so that ...here begins the text of the account'. The date of a Hadith is important. Imam Bukhari and Imam Muslim are considered to be authentic. Imam Bukhari collected 300,000 and kept only 8,000 Hadith (Mernessi 1987: 42- 48: Sabbah 1984). 
${ }^{12}$ Sunni sect of Muslims which comprises most of the Muslim population. Shia is the second largest sect.

${ }^{13}$ The translation of the specific verses into English have been done by Pickthall (1979), Arberry (1974), Zakaria (1991), Turner (1997). Translation by Colin Turner, are used here, as it is the most recent. It is noteworthy that in his translation of references to purdah dress he uses the words 'scarf and shawl', which are recently adopted forms of dress to cover head and body. This illustrates how translations reflect the linguistic norms of the period of times in which the translation was made.

${ }^{14}$ The Hadith referred are taken from various books but the original sources are alBukhari, al-Tirmazi and Abu Daud.

${ }^{15}$ Ayesha Khan (1999: 25) work indicates that burqa was invented in Turkey and became in vogue in the 1920's as a means to facilitate women's mobility outside the house. According to the glossary in Moghadam (1994a: 439) burqa is a Pushtu word for tentlike veil for Afghani women and Pushtus (Pathans living in North-West Frontier Province) in Pakistan. But the records of Indian history show that burqa was in vogue among the Turks in the thirteenth century, than they invaded India they introduced this type of purdah dress to the local culture (Kaur 1968; Misra 1965).

${ }^{16}$ Conformity to these various restrictions depends on the government's attitude towards women's issues. As the present government of General Musharraf is liberal, in 2002, of the CommonWealth Games in Manchester a Pakistan woman participated in swimming competitions. This would have been unthinkable during Zia-ul -Haq's time or during later period of the Muslim League's term of government.

\section{References:}

Encyclopedia Britannica.com. http://www.britannica.com/ 2000

Afary Janet. (1998) The War Against Feminism in the Name of the Almighty: Making Sense of Gender and Muslim Fundamentalism, pp. 1- 18 in Women Living under Muslim laws. Dossier 21, September 1998.

Ahmed, Leila. (1992) Women and Gender in Islam: Historical Roots of a Modern Debate, Yale University Press, New Haven.

Ahmed, Leila. (1992) Early Islam and the Position of Women: The Problem of Interpretation, pp. 58- 73 in Keddie, Nikki R. and Baron, Beth (eds.) Women in Middle Eastern History: Shifting Boundaries in Sex and Gender, Yale University Press New Haven. 
Ali, Shaheen Sarder. (2000) Gender and Human Rights in Islam and International Law. The Hague: Kluwer Law International.

Ali, Syed Mohammed. (2004) The Position of Women in Islam: a progressive view, Albany, State University of New York.

Ali, Syed Mumtaz. \& Mills, Rabia. (eds.) (2001) Social degradation of women a crime and a libel on Islam: The un-Islamic Indian-style Purdah System (hijab) is a case of Religious Overkill! by Marmaduke Pickthall. http://muslim-canada.org/pickthall.htm dated $2 / 5 / 02$.

Altekar, A. S. (1956) Position of Women in Hindu Civilization from Prehistoric Times to the Present Day, Benares: Motilal Banarsidas.

Arberry, Arthur J. (1974) The Quran Interpreted, Machmillan Publishers, New York.

Badran, Margot. (1993) Independent Women: More Than a Century of Feminism in Egypt, pp. 129- 147 in Tucker, Judith E. (ed.) Arab Women: Old Boundaries, New Frontiers, Indiana University Press, Indiana.

Badran, Margot. (1995) Feminists, Islam and Nations: Gender and the Making of Modern Egypt, Princeton University Press, Princeton.

Berninghausen, J. and Kerstan, B. (1992) Forging New Paths, Zed Books Ltd. (Translated by Barbara A. Reeves), London.

Bhatty, Zarina. (1976) Status of Muslim Women and Social Change, pp. 99-112, in Nanda, B. R. (ed.) Indian Women: From Purdah to Modernity, Vikas Publishing House PVT LTD ,New Delhi, India.

Bodman H.L. and Tohidi, Nayereh (1998) (eds.) Women in Muslim Societies: Diversity within Unity, Lynne Rienner Publishers, Colorado.

Boutta, Cherifa. (1994) Feminine militancy: Moudjahiates during and after the Algerian War, pp. 18- 39 in (ed.) by Moghadam, Valentine M. Gender and National Identity, United Nations University World Institute for Development Economic Research ,Helsinki.

Brijbhushan, Jamila. (1980) Muslim Women: In Purdah and Out of It, Vikas Publishing House, New Delhi, India.

Bullock, Katherine. (2000) Challenging Media Representations of Veil: Contemporary Muslim Women's Re-veiling Movement, pp. 22- 53 in The America Journal of Islamic Social Sciences, V.17, No: 3. International Institute of Islamic Thought (IIIT) \& Association of Muslim Social Scientists (AMSS). 
Charrad M. M. (1998) Cultural Diversity within Islam: Veils and Laws in Tunisia, pp. 63- 78 in Bodman H.L. and Tohidi, Nayereh (eds.) Women in Muslim Societies: Diversity within Unity, Lynne Rienner Publishers ,Colorado.

Cherifati-Merabtine, Doria. (1994) Algeria at crossroads: national liberation, Islamization and women, pp. 40- 62 in Moghadam, Valentine M. (ed.) Gender and National Identity, United Nations University World Institute for Development Economic Research, Helsinki.

Donzel, E.Van. (ed) (1978) Encyclopedia of Islam. Vol. 5 Leiden: Koninklijke Brill. E.J. Brill.

El Guindi, Fadwa. (1999) Veil: Modesty, Privacy and Resistance, Berg Publishers, Oxford.

Engineer, Asghar Ali. (1992) The Rights of Women in Islam, Vanguard, London.

Engineer, Asghar Ali. (1999) The Quran Women and Modern Society, Sterling Publishers Private Limited, New Delhi, India.

Gilani, Riazul Hasan. (1990) A Note on Islamic Family Law and Islamization in Pakistan, pp. 339- 345 in Mallat, Chibli and Connors, Jane (eds.) Islamic Family Law, Graham and Trotman, London.

Gole, Nilufer. (1996) The Forbidden Modern: Civilizing and Veil, The University of Michigan Press, Michigan.

Haddad, Yvonne Yazbeck. (1982) The Case of the Feminist Movement. pp. 54 - 70, In Contemporary Islam and the Challenge of History, State University of New York Press, Albany.

Haque, Riffat. (2002) The relationship between purdah, public policy, and exploitation of women in Pakistan, pp. 72- 77 in Lovejoy F. and Adorjany L. (ed.) New Sociology: Awareness, Analysis, Advocacy, School of Sociology, University New South Wales, Sydney.

Hafeez, Sabeeha. (1991) The Changing Pakistani Society ,Royal Book Company, Karachi, Pakistan.

Hassan, Riffat. (2001) Challenging the stereotypes of Fundamentalism: An Islamic feminist perspective, pp. 55- 69 in The Muslim World. Vol.91, issue 1\&2, Spring 2001, Hartford Seminary, New York. 
Hassan, Riffat. (2002) Islam and Human Rights. The Dawn. (Newspaper) $14^{\text {th }}$ November 2002, Karachi. www.dawn.com.

Hijab, Nadia. (1988) Women power: The Arab debate on Women at work. Cambridge University Press, Cambridge.

Hosseini, Ziba Mir. (1996) Women and Politics in post-Khomeini Iran: divorce, veiling and emerging feminist voices, pp. 142- 170 in Afshar, Haleh (ed.) Women and Politics in Third World, Routledge, London.

Hofmann, M.W. (1999) On the Development of Islamic Jurisprudence, in American Journal of Islamic Social Sciences, Vol.16, no 1S.The International Institute of Islamic Thought, Washington D.C.

Hussain, Freda. (ed.) (1984) Muslim Women, Croom Helm, London.

Ismail, Salwa. (1998) Confronting the other: Identity, Culture, Politics, and conservative Islamism in Egypt, pp. 214. International Journal of Middle East Studies, vol. 30, no. 2, May 1998, Cambridge University Press, Cambridge.

Jacobson, Doranne. \& Wadley, Susan S. (1977) Women in India: Two Perspectives, South Asia Books, New Delhi, India.

Jaschok, Maria and Jingjun, Shui. (2000) The History of Women's Mosques in Chinese Islam, Curzon Press, Richmond.

Jeffery, Patricia. (1979) Frogs in a Well: Indian Women in Purdah, Zed Press, London.

Jilani, Hina. (1994) Law as an Instrument of Social Control, pp. 96- 105 in Khan et.al. (eds.) Locating the Self: Perspectives on Women and Multiple Identities, ASR Publications, Lahore, Pakistan.

Kader, Soha Abdel. (1984) Survey of Trends in Research on Women, in Social Science Research and Women in the Arab World, Paris: Frances Pinter, UNESCO / London.

Kaur, Manmohan. (1968) Role of Women in the Freedom Movement (1947-1957). Sterling Publishers Private, Delhi, India.

Keddie, N R. and Beck, L. (1978) (eds.) Women in the Muslim World, Harvard University Press, London. 
Korvin, Gabor. (2000) Women's Leadership through the History of Islam, pp. 29-63 in Journal of the Pakistan Historical Society, Jan-Mar 2000, vol. XLVII, No. 1. Madinat al-Hikmat: Publishers Bait al-Hikmat.

Keddie, Nikki R. (1992) Introduction: Deciphering Middle Eastern Women's History, pp. 1- 22 in Keddie, Nikki R. and Baron, Beth (eds.) Women in Middle Eastern History: Shifting Boundaries in Sex and Gender. Yale University Press, New Haven.

Khan, Ayesha. (1999) Rhetoric and Reform: Feminism Among Indian Muslims, 19001940, ASR Publications, Lahore, Pakistan.

Khan, M. Farooq. (2004) Man and Woman: Social Relations in Islam, Organization for Research and Education, Islamabad, Pakistan.

Klein, H. G. and Nestvogel, R. (1992) Women in Pakistan, Vanguard books Ltd, Lahore.

Lawrence, Bruce B. (1998) Shattering the Myth: Islam Beyond Violence, University Press Princeton, Princeton.

Lateef, Shahida. (1990) Muslim Women in India, Political and Private Realities: 1890s1980s, Kali for Women, New Delhi, India.

MacEION, Denis and Al-Shahi, Ahamed. (eds.) (1983) Islam in the Muslim World, St. Martin's Press, New York.

Maududi, Abul Ala. (1934) Purdah and the Status of Women in Islam, Islamic Publications, Lahore, Pakistan.

Maumoon, Dunya. (1999) Islamism and Gender Activism: Muslim Women's quest for autonomy, pp. 269- 283, Journal of Muslim Minority Affairs, vol. 19. Issue 2 October 1999, Abingdon.

http://proquest.umi.com/pqdlink. (6/8/01).

Mernissi, Fatima. (1987) Beyond the Veil: Male-Female Dynamics in Modern Muslim Society, Al Saqi Books, London.

Mernissi, Fatima. (1991) The Veil and the Male Elite, Reading: Addison-Wesley Publishing Company.

Mernissi, Fatima. (1993) Women in Islam: an historical and theological inquiry, Kali for Women, New Delhi, India. 
Minault, Gail. (1982) Purdah Politics: The Role of Muslim Women in Indian Nationalism, 1911-1924, pp. 245- 260, in (eds.) by Papanek, Hanna and Minault, Gail. Separate Worlds: Studies of Purdah in South Asia. Chanakya Publishers, New Delhi, India.

Minturn, Leigh. (1993) Sita's Daughters: Coming Out of Purdah, Oxford University Press, New York.

Misra, Rekha. (1967) Women in Mughal India (1526- 1748 A.D.), Munshiram Manoharlal Oriental Publishers, Delhi.

Moghadam, Valentine M. (ed.) (1994) Identity Politics and Women: Cultural Reassertions and Feminisms in International Perspective, West view Press, San Francisco.

Mohammad, Sherif. (1995) Women in Islam verses Judaeo-Christian Tradition: The Myth \& The Reality. Ontario. (28-page booklet printed from internet).

Mojab, Shahrzad. (1998) Muslim women and western feminists: the debate on particulars and universals'. Monthly Review, Dec 1998 v50 i7. pp. 1- 11. http://web2.inftrac.galegroup.com (1/2/02).

Mumtaz, Khawar and Shaheed, Farida. (1987) Women of Pakistan: Two Steps Forward, One Step Back? Vanguard, Lahore, Pakistan.

Nashat, Guity. (1983) (ed.) Women and Revolution in Iran, West view Press, Colorado \& Boulder.

Papanek, Hanna. (1982) Purdah: Separate Worlds and Symbolic Shelter, pp. 3-53 in Papanek, Hanna and Minault, Gail. (eds.) Separate Worlds: Studies of Purdah in South Asia, Chanakya Publications, Delhi, India.

Pearl, David. (1990) Three Decades of Executive, Legislative and Judicial Amendments to Islamic Family Law in Pakistan, pp. 321-338 in Mallat, Chibli and Connors, Jane (eds.) Islamic Family Law. Graham and Trotman, London.

Pickthall, Marmaduke. (1979) The Glorious Quran. Kutab Khana Ishayat-ul-Islam. (2nd edition), Delhi.

Rehman, Fazlur. (1978) Islam and Modernity, University of Chicago Press, Chicago.

Roded, Ruth. (2001) Mainstreaming Middle East Gender Research: Promise or Pitfall?, pp. 15- 23, in Middle Eastern Studies Association Bulletin. v. 35, n.1. Summer 2001. U.S.A. 
Ruthuen, Malise. (1984) Islam in the World. Penguin Books, New York.

Saadawi, Nawal al. (1980) The Hidden Face of Eve. Zed Books, London.

Saadawi, Nawal al. (1986) Toward Women's Power, Nationality and internationally, pp. 247- 257 in Diana L. Eck and Deraki Jain (ed.) Speaking of Faith. Kali for Women, New Delhi, India.

Sabbah, Fatna A. (1984) Women in the Muslim Unconsciousness. Pergamon Press. (Translated by Mary Jo Lakeland), New York.

Saiyid Dushka. (1998) Muslim Women of the British Punjab. Macmillan Press Ltd, London.

Shaheed, Farida. (1987) Purdah and Poverty in Pakistan, pp. 17- 42 in Afshar, H. \& Agarwal, B. (eds.) Women, Poverty and Ideology in Asia. The Macmillan Press, London.

Shaheed, Farida. (1991) The Cultural articulation of Patriarchy, pp. 135- 158, in Zafar, Fareeha. (ed.) Finding Our Way, ASR, Lahore, Pakistan.

Siddiqi, M. Mazheruddin. (1979) Women in Islam. Institute of Islamic Culture, Lahore, Pakistan.

Stowasser, Barbara F. (1993) Women's Issues in Modern Islamic Thought, by (ed.) Tucker Judith E. Arab Women, Indiana University Press, Washington DC.

Stowasser, Barbara F. (1994) Women in the Quran, Traditions, and Interpretation, Oxford University Press, New York.

Stowasser, Barbara F. (1996) Women and Citizenship in the Quran, pp. 23 - 38 in (ed.) by Sonbol, Amira El Azhary. Women, the Family, and Divorce Laws in Islamic History, Syracuse University Press, Syracuse.

Thomas, P. (1964) Indian Women through the Ages, Asia Publishing House, Bombay.

Tohidi, Nayereh. (1991) Gender and Islamic Fundamentalism: Feminist Politics in Iran', pp. 251- 270 in Mohanty, C. T., Russo, A., Torres, L. (eds.) Third World Women and the Politics of Feminism, Indiana University Press, Bloomington and Indianapolis. 
Tohidi, Nayereh. (1994) Modernity, Islamization, and women in Iran', pp. 110- 147 in Moghadam, V. (ed.) Gender and National Identity Helsinki: United Nations University/ World Institute of Development Economics Research.

Tohidi, Nayereh. (1998) The Issues At Hand, pp. 277- 294 in Bodman H.L. and Tohidi, Nayereh (eds.) Women in Muslim Societies: Diversity within Unity, Lynne Rienner Publishers, Colorado.

Turner, C. (1997) The Quran: A New Interpretation. Richmond Surrey: Curzon Press.

Wadud-Muhsin, Amina. (1992) Quran and Women. Kuala Lumpur: Penerbit Fajar Bakti SDN. BHD.

Wassef, Nadia. (2001) On Selective Consumerism: Egyptian Women and Ethnographic Representations, pp. 111- 123 in Feminist Review No. 69, Winter 2001. http://www.tandf.co.uk/journals.

Zafer, Fareeha. (1991) (ed.) Finding our way, ASR Publication, Lahore, Pakistan.

Zakaria, Rafiq. (1991) Muhammad and the Quran, Penguin Books, London.

Dr. Riffat Haque is head of Women's Studies Department, Allama Iqbal Open University, Islamabad, Pakistan. Her areas of interest are: Women and Gender Studies, Development, Women and Islam, Gender and Environment, Distant and Non formal Education. 